\title{
The Paleontological Heritage of Northern Tocantins State and Southwest Maranhão State, Brazil: a Preliminary Synthesis
}

\author{
O patrimônio paleontológico do norte do estado do Tocantins e \\ sudoeste do Maranhão, Brasil: uma síntese preliminar
}

\section{El patrimonio paleontológico del norte del estado de Tocantins y suroeste de Maranhão, Brasil: una síntesis preliminar}

Raylon da Frota Lopes https:/ / orcid.org/0000-0002-1715-0975

lopesraylon@gmail.com Universidade Federal de Goiás, UFG, Goiânia, GO

Claudia Valéria de Lima https:/ / orcid.org/0000-0001-9991-2541 claudia@ufg.br Universidade Federal de Goiás, UFG, Goiânia, GO

Carlos Roberto A. Candeiro https:/ / orcid.org/0000-0002-8128-4660 candeiro@ufg.br Universidade Federal de Goiás, UFG, Aparecida de Goiânia, GO

\begin{abstract}
This paper aims to present a preliminary synthesis of the Paleontological Heritage of northern Tocantins State and southwest Maranhão State. It is a compound mainly from Paleozoic and Mesozoic rocks of the intracratonic Parnaíba Basin. Fossils from these regions include body fossils of sharks, gymnosperm trunks, mineralized ferns, ichnofossils of sauropods and theropods, and indeterminate leaf molds.
\end{abstract}

Keywords: Geodiversity, Parnaíba Basin, fossiliferous survey.

Resumo: Este artigo visa apresentar uma síntese preliminar do patrimônio paleontológico da região norte do estado do Tocantins e sudoeste do Maranhão, proveniente, em sua maioria de rochas com gênese no Paleozoico e Mesozoico da Bacia Intracratônica do Parnaíba. Os fósseis consistem em somatofósseis de tubarões, troncos de gimnospermas, e samambaias mineralizados, icnofósseis de saurópodes e terópodes, e moldes de folhas indeterminados.

Palavras-chave: Geodiversidade, Bacia do Parnaíba, levantamento fossílífero.

Resumen: Este trabajo tiene como objetivo presentar una síntesis preliminar del patrimonio paleontológico de la región norte del estado de Tocantins y suroeste 
de Maranhão, principalmente de las rocas de génesis paleozoica y mesozoica de la Cuenca Intracratónica de Parnaíba. Los fósiles consisten en somatofósiles de tiburones, gimnospermas y troncos de helechos mineralizados, icnofósiles de saurópodos y terópodos, y moldes de hojas indeterminadas.

Palabras clave: Geodiversidad, Cuenca del Parnaíba, investigación fosilífera.

\section{INTRODUCTION}

The Paleontological Heritage of northern Tocantins State and southwest Maranhão State, Brazil, is mostly comprised of paleobiological records preserved in rocks that originated in the intracratonic Parnaíba Sedimentary Basin during the Paleozoic and Mesozoic eras (Alves, 2010). The fossiliferous outcrops from this region are present in rocks from the geological formations Motuca (Permian), Pedra de Fogo (Permian), Sambaíba (Triassic), Corda (Cretaceous), and Codó (Cretaceous).

The fossils found in these geological units consist of body fossils of sharks, gymnosperm trunks, mineralized ferns, ichnofossils of sauropods and theropods, and indeterminate leaf molds (Santos; Carvalho, 2009; Assis et al., 2010; Kauffmann et al., 2013; De Valais et al., 2015).

Recently, researchers of the Universidade Federal de Goiás have been conducting fieldworks at potential prospective areas to recover, inventory, map, and describe the paleobiological diversity of the region as, despite its importance, most of the previously known fossil records do not have, to date, descriptive nor systematic studies on them.

The region under study is located in the northwest region of the intracratonic Parnaíba Sedimentary Basin, in North Tocantins State and Southwest Maranhão State, covering an area of approximately $82,000 \mathrm{~km}^{2}$. The present work aims to inventory the paleontological heritage of this region based on data obtained from the geological and paleontological literature and fieldwork findings.

\section{GEOLOGICAL CONTEXT}

\section{Parnaíba Basin}

The intracratonic Parnaíba Basin comprises an area of $600,000 \mathrm{~km}^{2}$ in the north and northeast regions of Brazil which comprises the states of Tocantins, Pará, Maranhão, Piauí, Ceará, and Bahia (Fig. 1). During the Paleozoic Era, the sedimentation process covered much of the Brazilian territory, including this geological unit, as well as a portion of the Taoudeni Basin, in Africa (Aguiar, 1971; Góes \& Feijó, 1994). 
Figure 1: Parnaíba Sedimentary Basin and the study area.
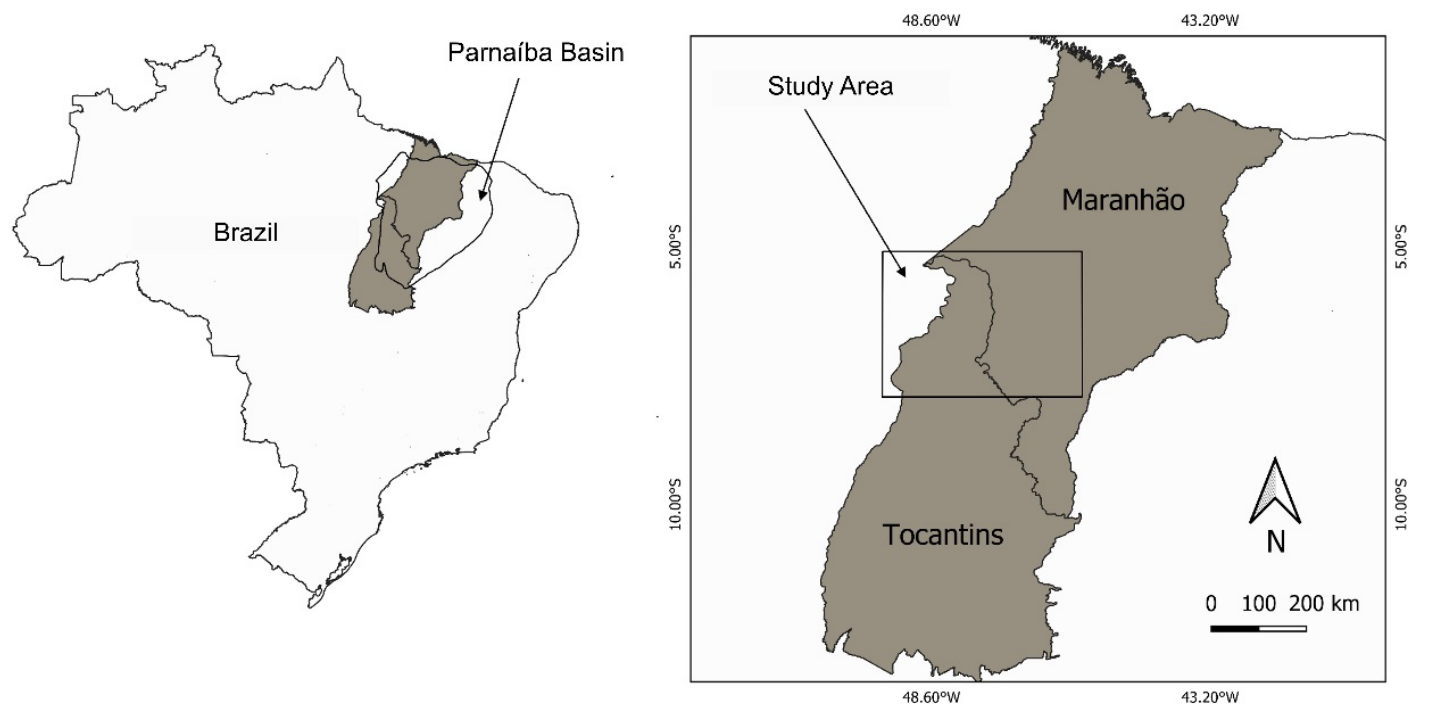

Source: IBGE (2018), GEOSGB (2018). Geographic coordinate system: SIRGAS 2000.

The outset of the depositional system of this basin and other Brazilian intracratonic basins - such as the Solimões, Amazonas, and Paraná basins - occurred by the end of the Ordovician, after the Brazilian-Pan-African thermo-tectonic cycle (Cunha, 1986, Caputo et al., 2005). The stratigraphic understanding of the Parnaíba Basin was given by the studies performed on its outcrops and published mainly in the last decades, together with the technical works performed by the publicly-held company Petrobras (Aguiar, 1971; Góes \& Feijó, 1994; Vaz et al., 2007).

\section{Motuca Formation}

This geological unit was described by Plummer et al. (1948) to assign the reddish shales with calcareous and anhydrite lenses that outcrops at Motuca Farm, between the municipalities of São Domingos and Benedito Leite (MA). Melo and Prade (1968) suggested subdividing this formation into three members: the Lower Member is mainly consisted of fine to very fine reddish sandstones; the Middle Member is formed by intercalated siltstones with carbonate banks usually succeeded by thicker layers of gypsum and/or anhydrite, and the Upper Member is predominantly composed of very fine sandstones to red siltstones.

The paleoenvironment of the Motuca Formation is understood as shallow lake and continental sabkha, under several sedimentation conditions (fluvial, lacustrine, and aeolian) and episodes of marine transgression at the middle portion of the section with gypsum deposition (Lima \& Leite, 1978).

\section{Pedra de Fogo Formation}

The Pedra de Fogo Formation was formalized by Plummer et al. (1948) and outcrops especially at the central region of the Parnaíba Basin, along an extensive area of approximately 
$600 \mathrm{~km}$ in the east-west direction of the states of Piauí, Maranhão, and the north-center Tocantins.

This unit occurs on the surface with an average thickness of $100 \mathrm{~m}$ and is lithologically subdivided into three members: Basal Quartzite, Middle, and Upper or "Trisidela". The Basal Quartizite member consists of fine sandstones, siltstones, and shales interspersed with dolomitic banks and siliceous concretions. The Middle member mostly presents sandstone sequences with cross-stratification overlapped by fine-grained sediments (siltstones and shales), with the upper layers composed of carbonate banks associated with silica concretions (Faria Jr \& Truckendrodt, 1980).

The Upper member (or "Trisidela") is mainly present at the central and west areas of the basin and is composed of carbonate laminates of shale, chert strata, sandstone and siltstone deposits, and fossil plants (Plummer et al., 1948; Faria Jr, 1979; Faria Jr \& Truckendrodt, 1980).

The paleoenvironment of this formation is interpreted as shallow marine and coastal with sabkha plains, under the occasional influence of storms (Góes \& Feijó, 1994). Depositional cycles can be identified in the succession of layers of this unit (Aguiar, 1971).

\section{Sambaíba Formation}

The Sambaíba Formation was first described by Plummer et al. (1948) to characterize the sandstones that form the plateaus observed in the municipality homonymous to this formation. This unit is represented by sandstones with large planar and cross-channel stratifications (Aguiar, 1971).

These large cross-stratification sandstones containing several typical features of aeolian sediments characterize a desert system with fluvial contribution (Vaz et al., 2007). The upper contact of the Sambaíba Formation occurs with the Lower Jurassic basaltic spills of the Mosquito Formation (Góes \& Feijó, 1994). This unit was historically considered as non-fossiliferous because its sedimentation environment shows the occurrence of intense desertification in the mega continent Pangea during the Triassic. Nevertheless, ichnofossils from theropod vertebrates were already reported in this locality (Santos \& Carvalho, 2009; Assis et al., 2010).

\section{Corda Formation}

The Corda Formation outcrops in the central portion of the Parnaíba Basin. The lithology of this unit consists of very fine or fine to medium sandstones that are red, reddishbrown, white, or purple to gray in color and rich in iron oxide and zeolites (Aguiar, 1971).

The predominant sedimentary structures in the Corda Formation are large-sized, grain-flow bundles with cross-channel stratification intercalated by layers with planeparallel stratification. These structures are interpreted as aeolian dune and interdune deposits (Aguiar, 1971).

The sedimentation process of this unit was attributed to a desert environment with dry, hot, fluvial climatic conditions of high energy in its interior, deposited in the distal 
portion of a braided river system. In this context, it can be said that the preservation of fossils was a rare event (Santos \& Carvalho, 2009).

\section{Codó Formation}

The Codó Formation comprises a sequence of shales, limestones, and intercalated evaporates that cover an area of about $170,000 \mathrm{~km}^{2}$ in the Maranhão State. Its sediments are horizontally and sub-horizontally arranged with a maximum thickness of about 180 m (Fernandes \& Dela Piazza, 1978).

The unit is stratigraphically divided into two sedimentary sections. The lower one is composed of bituminous black shales progressing to limestones and evaporates, and the upper one, consists of intercalated pelites and sandstones of dark red and greenish color, and whitish to grayish limestones (Lindoso \& Carvalho, 2014).

The deposits of the Motuca Formation are attributed to depositional environments predominantly lacustrine, taking into account the physiological characteristics with mastery of lithologies formed by suspension and the absence of marine fossils (Ramos et al., 2006).

\section{MATERIAL AND METHODS}

\section{Material}

Cartographic databases and vector and matrix data from the Instituto Brasileiro de Geografia e Estatística (IBGE) and the Companhia de Pesquisa de Recursos Minerais (CPRM) were used to map the region using the software Qgis 3.14 to edit and analyze the georeferenced data. The fossil content illustrated or cited here are housed in situ or in the following institutions: Laboratório de Paleontologia e Evolução (Labpaleoevo) of the Universidade Federal de Goiás, A parecida de Goiânia Campus; Laboratório de Paleobiologia (LBPbiol) of the Universidade Federal do Tocantins, Porto Nacional Campus.

\section{Methods}

This study used the following methodological steps: (1) bibliographic survey on the theme and area under study; (2) fieldwork in one of the study areas to describe the outcrops and evaluate the condition of the paleontological and geological occurrences; (3) gathering and interpretation of data based on the analysis of the information collected from both literature and fieldwork; (4) elaboration of maps based on the data obtained in the previous steps. 


\section{RESULTS AND DISCUSSION}

Overall, the Paleontological Heritage from the studied area comprises a set of seven outcrops of discontinuous ages, ranging from the Permian to the Cretaceous. Among these outcrops, three are located in the Tocantins State and four are in the Maranhão State.

The fossils found in the rocks that outcrops in this region are records of sharks, gymnosperm trunks, and fossil ferns. There are also ichnofossils (footprint trails) of sauropod and theropod dinosaurs and indeterminate leaf molds (Fig. 2) (Santos \& Carvalho, 2009; Assis et al., 2010; Kauffmann et al., 2013; De Valais et al., 2015).

Figure 2: Paleontological Heritage of the Northern Tocantins and Southwestern Maranhão. Numbers indicate the localities.

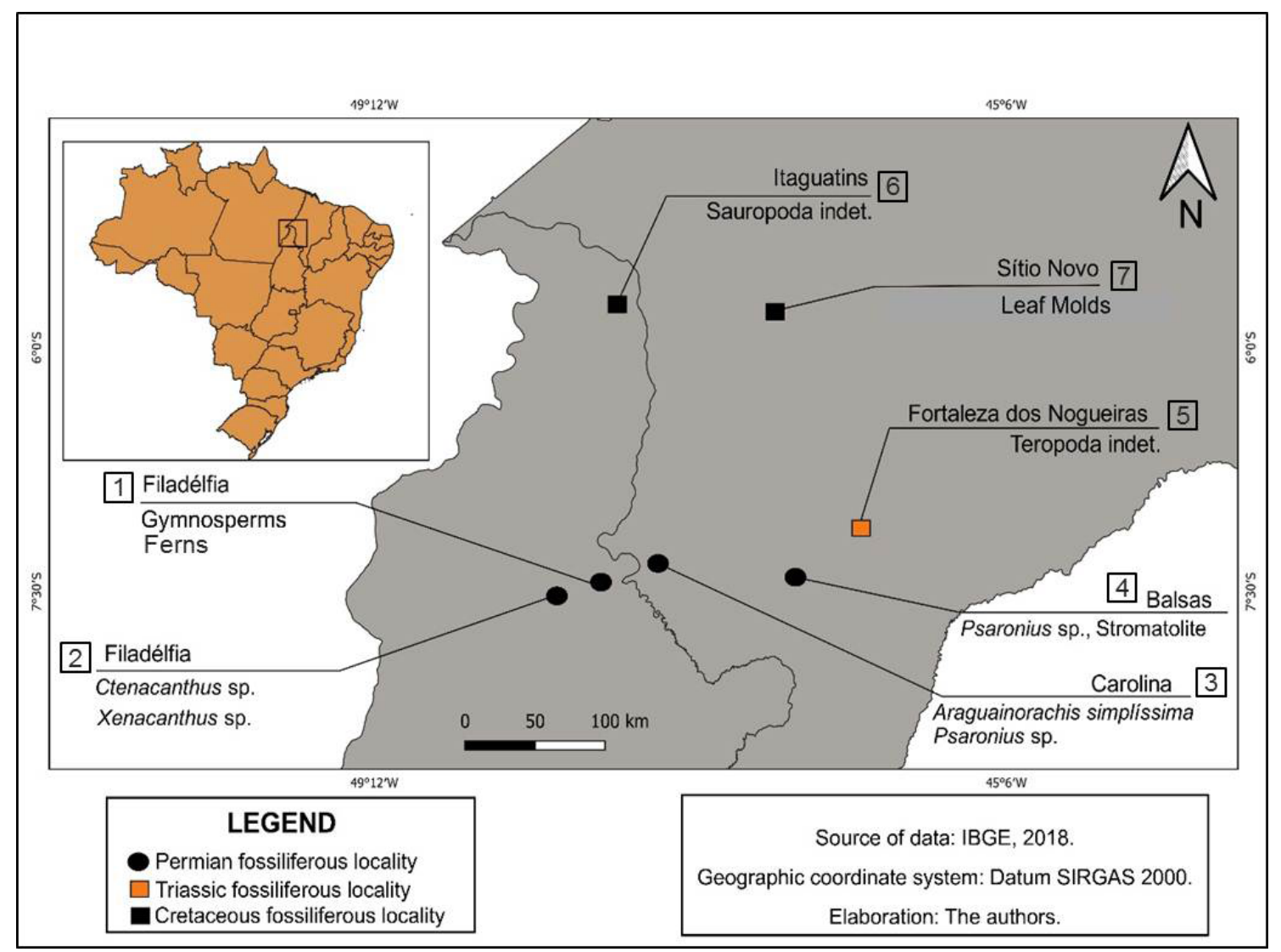

\section{Localities}

\section{1- Filadélfia (Tocantins State)}

Locality 1: Filadélfia municipality (TO), southwest of the town downtown. The geosites are part of the environmental conservation unit Monumento Natural das Árvores Fossilizadas do Tocantins (MONAF).

Coordinates: $7^{\circ} 17^{\prime} 45^{\prime \prime}$ and $7^{\circ} 38^{\prime} 34^{\prime \prime} \mathrm{S} ; 47^{\circ} 35^{\prime} 17^{\prime \prime}$ and $48^{\circ} 01^{\prime} 05^{\prime \prime} \mathrm{W}$.

Stratigraphic level: Motuca Formation. 
Age: Upper Permian (Lopingian).

Fossil record: Gimnosperms and fossilized ferns (Fig. 3).

Reference: Dias-Brito et al. (2009).

Figure 3: Permian phytofossils from Filadélfia, TO. A: fossilized gymnosperm trunk $(\mathrm{scale}=12 \mathrm{~cm})$; B: fossilized fern leaf $($ scale $=10 \mathrm{~cm}$ ).
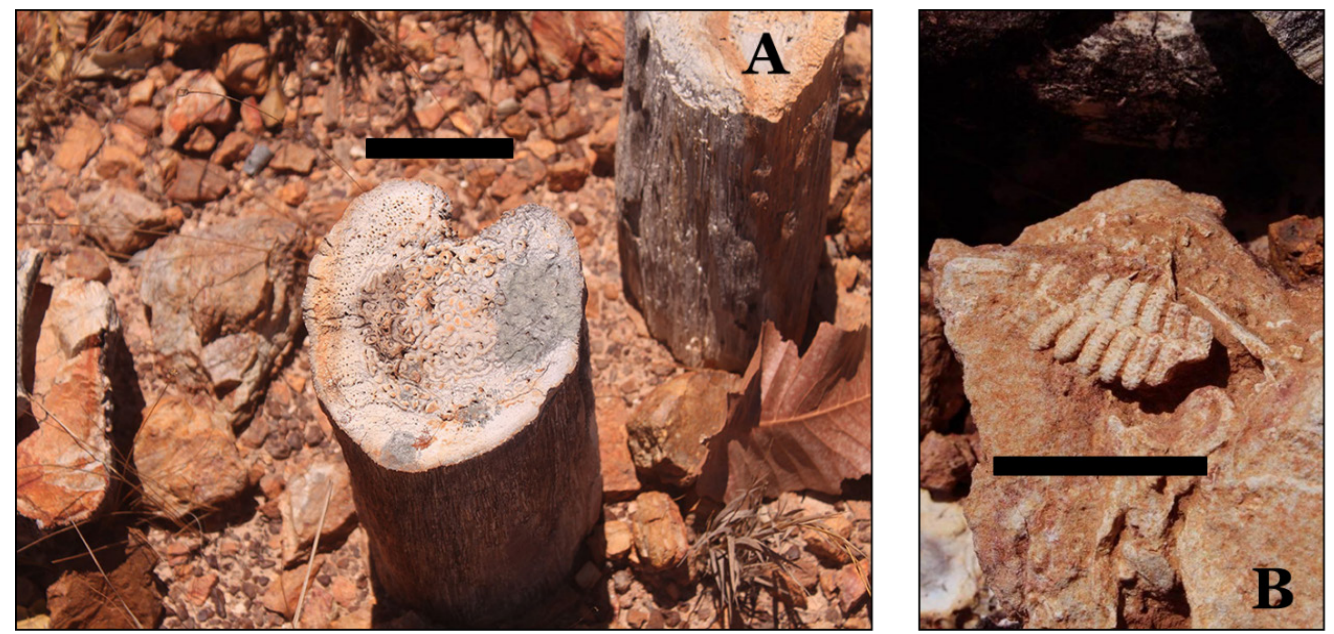

Photo: Carlos Eller.

\section{2- Filadélfia (Tocantins State)}

Locality 2: Filadélfia municipality (TO), $67 \mathrm{~km}$ southeast of the town downtown, following the road to the municipality of Araguaína.

Coordinates: $07^{\circ} 28^{\prime} \mathrm{S}, 47^{\circ} 56^{\prime} \mathrm{W}$.

Stratigraphic level: Pedra de Fogo Formation, Trisidela Member.

Age: Middle Permian (Kungurian).

Fossil record: fin spines of Ctenacanthus (Fig. 4); Xenacanthus teeth.

Reference: Alves (2010).

Figure 4: The distal portion of fin spine of Ctenacanthus sp., Pedra de Fogo Formation.

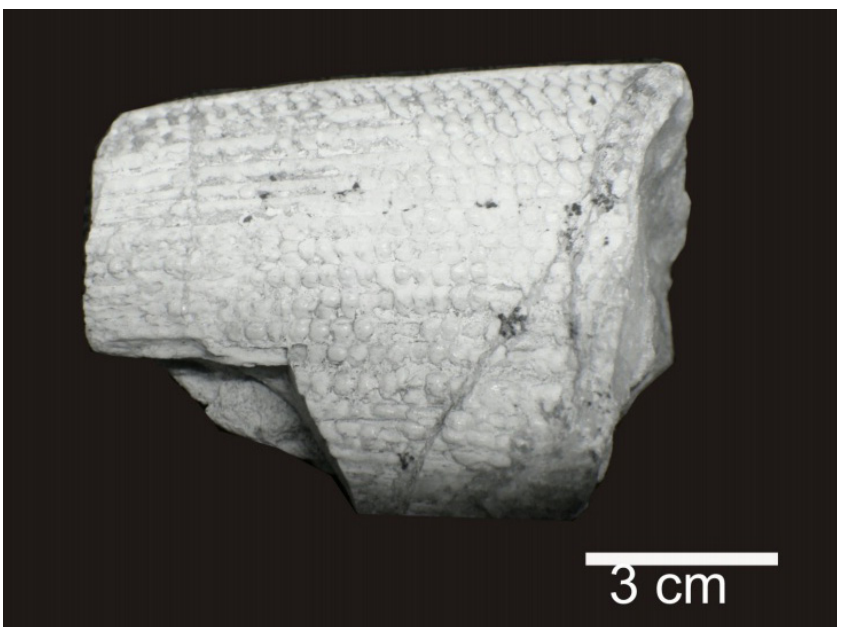

Source: Alves (2010). 


\section{3- Carolina (Maranhão State)}

Locality 3: Morro do Corró, $3 \mathrm{~km}$ south of the municipality of Carolina (MA), CarolinaRiachão highway.

Coordinates: $7^{\circ} 19.800^{\prime}$ S, $47^{\circ} 27.600^{\prime} \mathrm{W}$.

Stratigraphic level: Motuca Formation.

Age: Upper Permian (Lopingian).

Fossil record: Araguainorachis simplissima, Psaronius sp.

Reference: Santos \& Carvalho (2009).

\section{4- Balsas (Maranhão State)}

Locality 4: Testa Branca farm, $15 \mathrm{~km}$ east of the Balsas (MA) municipality downtown. Coordinates: $07^{\circ} 23^{\prime} \mathrm{S}, 46^{\circ} 31^{\prime} \mathrm{W}$.

Stratigraphic level: Motuca Formation.

Age: Upper Permian (Lopingian).

Fossil record: Psaronius sp., stromatolites.

Reference: Santos \& Carvalho (2009).

\section{5- Fortaleza dos Nogueiras (Maranhão State)}

Localidade 5: banks of the Ribeirão das Lajes river, Fortaleza dos Nogueiras municipality (MA).

Coordinates: $7^{\circ} 05>24 » S, 46^{\circ} 05^{\prime} 22^{\prime \prime} \mathrm{W}$.

Stratigraphic level: Sambaíba Formation.

Age: Triassic.

Fossil record: indeterminate Theropoda footprint trails (Fig. 5).

Reference: Assis et al. (2010).

Figure 5: Footprint of an indeterminate Theropoda in Fortaleza dos Nogueiras (MA). Scale $=5 \mathrm{~cm}$.
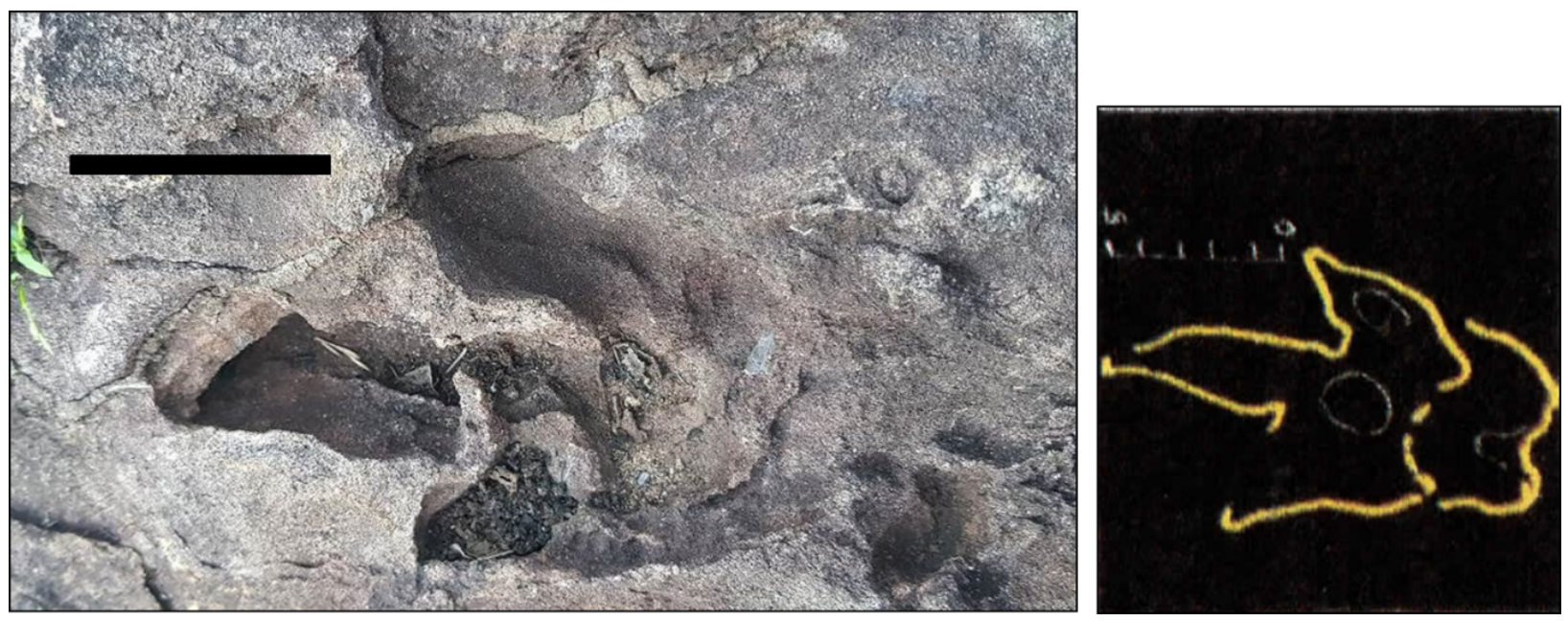

Source: Assis et al. (2010). 


\section{6- Itaguatins (Tocantins State)}

Locality 7: São Domingos village (TO), $5 \mathrm{~km}$ north of the municipality downtown. Coordinates: $5^{\circ} 42^{\prime} 58^{\prime \prime} \mathrm{S}, 47^{\circ} 29^{\prime} 48^{\prime \prime} \mathrm{W}$.

Stratigraphic level: Corda Formation.

Age: Cretaceous (Barremian).

Fossil record: footprints of indeterminate Sauropoda (Fig. 6).

Reference: Leonardi (1994), de De Valais et al. (2015).

Figure 6: Sauropoda footprints from the Cretaceous of Itaguatins (TO). A trail with three footprints where the closest one (a) is covered by modern sediments; (b) and (c) are moderately preserved footprints. Scale $=50 \mathrm{~cm}$.

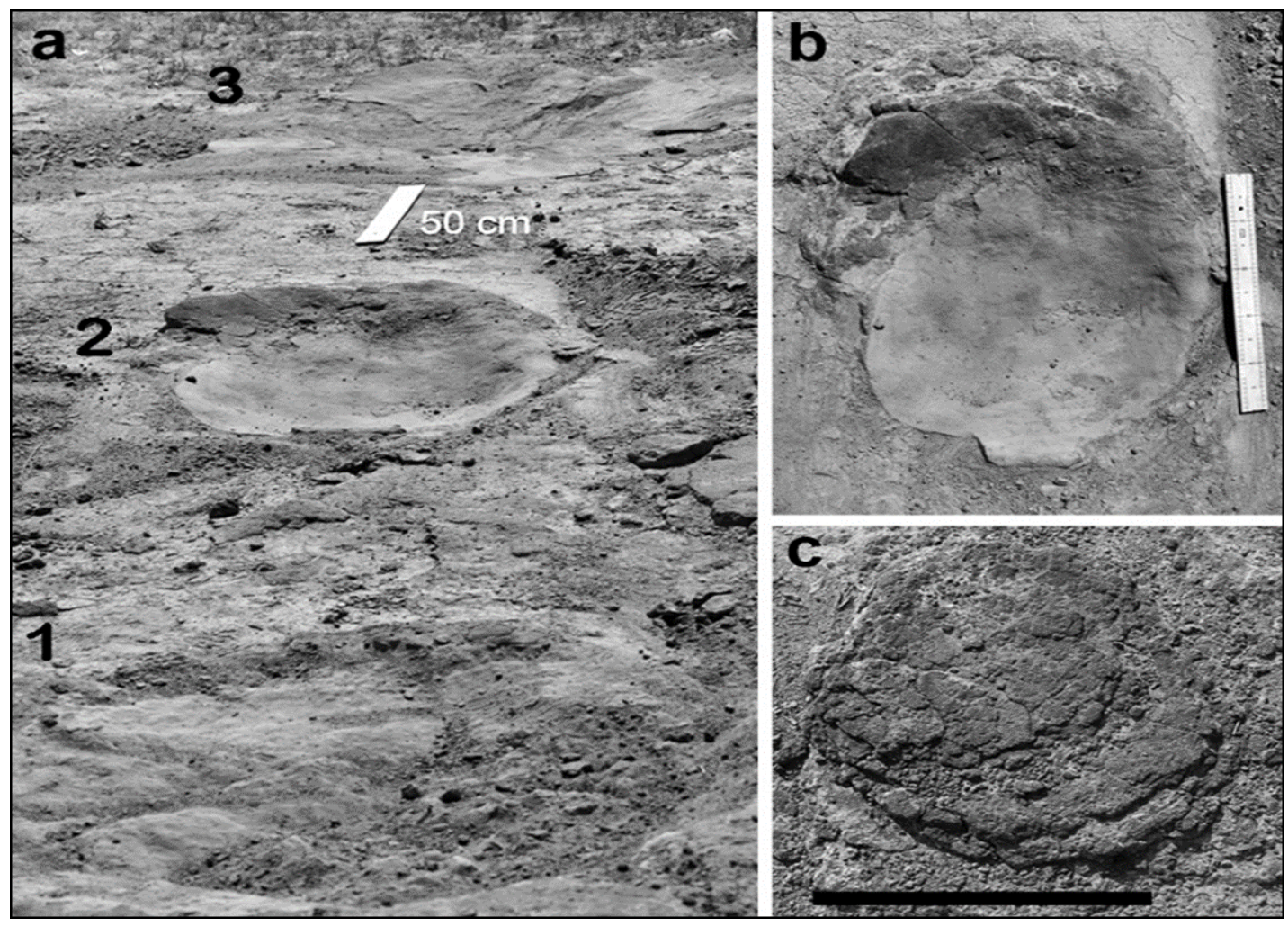

Source: De Valais et al. (2015).

\section{7- Sítio Novo (Maranhão State)}

Locality 6: Sítio Novo municipality (MA), $15 \mathrm{~km}$ north of the municipality downtown, at the road to Amarante do Maranhão municipality.

Coordinates: $05^{\circ} 45^{\prime} \mathrm{S}, 46^{\circ} 39^{\prime} \mathrm{W}$.

Stratigraphic level: Codó Formation.

Age: Cretaceous (Aptian-Albian).

Fossil record: Indeterminate leaf molds.

Reference: Lima \& Leite (1978); Santos \& Carvalho (2009). 
The fossil outcrops in the studied area are known to the scientific community since the middle of the last century, but few works have been carried out with the paleontological heritage of this region. This is mainly explained by the fragmentary nature of most specimens, which makes detailed description impossible. The results presented here show the paleontological richness of an area that is still little explored but has significant and diverse paleobiological records.

The Permian fossil-bearing outcrops in the Filadélfia municipality (TO), and in the municipalities of Carolina and Balsas (MA), are from the Lopingian to the Kungurian. The records from this geological stage include both animals and plants. The plant fossils are distributed in two distinct areas, one in the municipality of Filadélfia (TO) and the other in the municipality of Carolina (MA). Animal fossils are only present in one area in the municipality of Filadélfia.

In Filadélfia, the fossil plant record comprises gymnosperm trunks and fern leaves from the Motuca Formation rocks. The identified taxa are Botryopteris nollii, Dadoxylon sp., Grammatopteris freitasii, Pecopteris sp., Psaronius sp., and Tietea sp. (Tab. 1). The paleobiological record richness of this region, which is one of the largest fossilized forests in the world, has led to the creation of a protected area managed by the State government for the preservation of the paleontological heritage and scientific and educational purposes.

In the Carolina municipality (MA) the presence of fossil plants is characterized by Araguainorachis simplíssima and Psaronius sp., discovered in a rural area nearby the BR-230 road. This finding, in addition to the records from Filadélfia, shows the paleobiological richness of the studied area.

Table 1: Fossils of the studied area and their respective taxa, locations, and geological units.

\begin{tabular}{|c|c|c|c|c|}
\hline Taxa & Locality & Geological Unit & Age & Reference selected \\
\hline $\begin{array}{l}\text { Botryopteris nollii } \\
\text { Dadoxylon sp. } \\
\text { Grammatopteris freitasii } \\
\text { Pecopteris sp. } \\
\text { Psaronius sp. } \\
\text { Tietea sp. }\end{array}$ & Filadélfia, TO & Motuca Formation & $\begin{array}{l}\text { Permian } \\
\text { (Lopingian) }\end{array}$ & Dias-Brito et al. (2009) \\
\hline $\begin{array}{l}\text { Xenacanthus sp. } \\
\text { Ctenacanthus sp. }\end{array}$ & Filadélfia, TO & $\begin{array}{l}\text { Pedra de Fogo } \\
\text { Formation, Trisidela } \\
\text { Member }\end{array}$ & $\begin{array}{l}\text { Permian } \\
\text { (Kungurian) }\end{array}$ & $\begin{array}{l}\text { Santos \& Carvalho (2009) } \\
\text { Alves (2010) }\end{array}$ \\
\hline $\begin{array}{l}\text { Araguainorachis simplíssima } \\
\text { Psaronius sp. }\end{array}$ & Carolina, MA & Motuca Formation & $\begin{array}{l}\text { Permian } \\
\text { (Lopingian) }\end{array}$ & Santos \& Carvalho (2009) \\
\hline $\begin{array}{l}\text { Psaronius sp. } \\
\text { Stromatolites }\end{array}$ & Balsas, MA & Motuca Formation & $\begin{array}{l}\text { Permian } \\
\text { (Lopingian) }\end{array}$ & Santos \& Carvalho (2009) \\
\hline Teropoda indet. & $\begin{array}{l}\text { Fortaleza dos } \\
\text { Nogueiras, MA }\end{array}$ & Sambaíba Formation & Triassic & Assis et al. (2010) \\
\hline Sauropoda indet. & Itaguatins, TO & Corda Formation & $\begin{array}{l}\text { Cretaceous } \\
\text { (Barremian) }\end{array}$ & $\begin{array}{l}\text { Leonardi (1994) } \\
\text { De Valais et al. (2015). }\end{array}$ \\
\hline Plantae indet. & Sítio Novo, MA & Codó Formation & $\begin{array}{l}\text { Cretaceous } \\
\text { (Aptiano- } \\
\text { Albiano) }\end{array}$ & $\begin{array}{l}\text { Lima \& Leite (1978) } \\
\text { Santos \& Carvalho (2009) }\end{array}$ \\
\hline
\end{tabular}


The paleontological record of Balsas (MA) is represented by Psaronius sp. and stromatolites from the Motuca Formation. These fossils were found at a farm $15 \mathrm{~km}$ east of the municipality. The preservation of both fossil types in the same area can be explained by the marine transgression that occurred during the sedimentation event of the Motuca Formation. This event led to the fossil preservation of this plant typical of dry environments and of stromatolites that are usually formed in shallow-sea environments. The Permian animal fossils from the studied area are represented by fins pines of Ctenacanthus sp., and teeth of Xenacanthus sp., found nearby the TO-222 road. According to Alves (2010), these findings are similar to the specimens found in the Permian of Kansas (USA). However, they were described at a very inclusive taxonomic level, and further studies are still needed to understand these relationships.

The Triassic record in the studied area is represented by indeterminate Theropoda ichnofossils found at the Fortaleza dos Nogueiras municipality (MA). This finding comprises footprint trails from the Sambaíba Formation rocks described by Assis et al. (2010). Some authors (e.g. Santos \& Carvalho, 2009) consider this geological unit as non-fossiliferous. Thus, the advent of this finding reveals the need for studies about the stratigraphic positioning of the ichnofossils or even a better understanding of the palaeoenvironment and sedimentation process of this unit.

The Cretaceous fossil materials include indeterminate leaf molds from the Codó Formation, Sítio Novo municipality (MA), and ichnofossils represented by footprint trails of indeterminate Sauropoda found in the Corda Formation, Itaguatins municipality (TO).

The indeterminate leaf molds are mentioned by Lima and Leite (1978) and by Santos and Carvalho (2009), but there is no additional information or description other than the site locality. The indeterminate Sauropoda footprint trails were first reported by Leonardi (1980) and later described by De Valais et al. (2015). This finding consists of footprint trails assigned to a Diplodocoidea that has taxonomic similarities with taxa described in Africa. However, we believe that further studies on these taxa are crucial to allow more accurate inferences.

\section{FINAL CONSIDERATIONS}

The geological formations described here correspond to units with few known fossil records. Until now, the only known fossil records from the Corda and Sambaíba formations are the ones reported here. The paleontological heritage of the studied area is of great value as it comprises the ages from the last stages of the supercontinent Gondwana to the initial phase of separation, in addition to having potential educational and touristic importance.

Further researches are still needed for a better taxonomic understanding of the taxa mentioned here to increase the paleobiogeography and paleogeography knowledge of the studied area. Most fossiliferous outcrops mentioned in this work have a high degree of deterioration, which puts at risk the existence of these paleobiological records. In addition to works on systematic description, it is also necessary to perform geoconservationist studies 
on the paleontological heritage inventoried here to measure their values quantitatively and, thus, conceive appropriate geoconservation strategies for each geosite.

\section{ACKNOWLEDGMENTS}

To Capes (Coordenação de Aperfeiçoamento de Pessoal de Nível Superior) for funding doctoral research by Raylon Lopes.

\section{REFERENCES}

Aguiar, G.A. (1971). Revisão Geológica da bacia Paleozóica do Maranhão. Anais do Congresso Brasileiro de Geologia, São Paulo, SP, Brasil, 25. v. 3, pp.113-122. Available in http://sbg.sitepessoal.com/anais_ digitalizados/1971-S\%C3\%83O\%20PAULO/ANAIS_DO_XXV_CBG_V.1_(1971).pdf

Alves, Y.M. (2010). Report on the Upper Permian and Lower Cretaceous fossiliferous localities vertebratesbearing in the centralnorth of Tocantins State, Brazil. Brazilian Geographical Journal: Geosciences and Humanities research medium, 1(2),372-386.

Assis. F.P., Macambira. J.B, \& Leonardi,G. (2010). Dinossauros terópodes do Ribeirão das Lajes, primeiro Registro fóssil da Formação Sambaíba (Neotriássico-Eojurássico), Bacia do Parnaíba: Fortaleza dos Nogueiras, Maranhão-Brasil. 2010. Anais do Congresso Brasileiro de Geologia, Belém, PA, Brasil, 45. P.1720. Avaliable in http://sbg.sitepessoal.com/anais_digitalizados/2010-BEL\%C3\%89M/2010-BEL\%C3\%89M. zip

Caputo, M.V., Iannuzzi, R., \& Fonseca, V.M.M. (2005). Bacias sedimentares Brasileiras: Bacia do Parnaíba. Aracajú- SE. Informativo da Fundação Paleontológica Phoenix, 81,1-6.

Cunha, F.M.B. (1986). Evolução paleozóica da Bacia do Parnaíba e seu arcabouço tectônico. Dissertação de Mestrado. Instituto de Geociências, Universidade Federal do Rio de Janeiro, UFRJ, Rio de Janeiro, Brasil. Available in http://www.ppegeo.igc.usp.br/index.php/anigeo/article/view/1626

De Valais, S., Candeiro, C.R., Tavares, L.F., Alves, Y.M., \& Cruvinel, C. (2015). Current situation of the ichnological locality of São Domingos from the Corda Formation (Lower Cretaceous), northern Tocantins State, Brazil. Journal of South American Earth Sciences, 61,142-146.

Dias-Brito, D., Rohn, R., Castro, J.C., Dias, R.R., \& Rößler, R. (2009). Floresta petrificada do Tocantins Setentrional: o mais exuberante e importante registro florístico tropical-subtropical permiano no Hemisfério Sul. In M. Winge, C., Schobbenhaus, M. Berbert-Born, E. Queiroz, D.A. Campos, C.R.G. Souza, \& A.C.S. Fernandes (Eds.). Sitios Geológicos e Paleontológicos do Brasil. Brasília: CPRM. Available in http://sigep. cprm.gov.br/sitio104/sitio104.pdf

Faria Jr., L.E.C. (1979). Estudo sedimentológico da Formação Pedra de Fogo - Permiano - Bacia do Maranhão. Dissertação de Mestrado. Universidade Federal do Pará, UFPA, Belém, Brasil. Available in http:// repositorio.ufpa.br/jspui/handle/2011/8387

Faria Jr, L.E.C., \& Truckenbrodt, W. (1980). Estratigrafia e petrografia da Formação Pedra de Fogo, Permiano da Bacia do Maranhão. Anais do Congresso Brasileiro de Geologia, 31, Camboriu, SC, Brasil, 2. pp. 740-754. Available in http://sbg.sitepessoal.com/anais_digitalizados/1980-CAMBORIU/1980-CAMBORIU.zip

Fernandes, G., \& Della Piazza, H. (1978). O potencial oleogenético da Formação Codó. BoIetim Técnico da Petrobrás, 21(1), 3-16.

GEOSGB. Dados, informações e produtos do Serviço Geológico do Brasil. (2018). Unidades Geológicas. Rio de Janeiro: CRPM. Available in https://geoportal.cprm.gov.br/geosgb/

Góes, A.M.O., \& Feijó, F.J. (1994). Bacia do Parnaíba. Boletim de Geociências da Petrobrás, 8, 57-67. 
Instituto Brasileiro de Geografia e Estatística (2018). Malhas Territoriais 2018. Rio de Janeiro. Available de https://www.ibge.gov.br/geociencias/organizacao-do-territorio/malhas-territoriais/15774-malhas. html?edicao $=24048 \& \mathrm{t}=$ downloads

Kauffmann, M., Ricardi-Branco, F., Fabbrin, E.P.O., Benício, W.J., \&Jasper, A. (2013). Resultados preliminares do resgate de fitofósseis no Monumento Natural das Árvores Fossilizadas do Tocantins, Bacia do Parnaíba, Tocantins, Brasil. Revista Geonomos, 21(2), 46-52. Doi:10.18285/geonomos.v21i2.271.

Leonardi, G. (1980). Ornithischian trackways of the Corda Formation (Jurassic) Goias, Brazil. In: Abstract of Congreso Latinoamericano de Paleontología, Buenos Aires, Argentina, 1. pp. 215-222. Available in https:// www.researchgate.net/publication/309763045_Ornithischian_trackways_of_the_Corda_Formation_ Jurassic_Goias_Brazil .

Leonardi, G. (1994). Annotated Atlas of South America Tetrapod Footprints (Devonian to Holocene). Brasília: CPRM.

Lima, E.A.M., \& Leite, J.F. (1978). Relatório Técnico do Projeto Estudo Global dos Recursos Minerais da Bacia Sedimentar do Parnaíba - Integração Geológica-Metalogenética. (v.1, pp.124-132). Recife: Convênio DNPM CPRM.

Lindoso, R.M., \& Carvalho, I.S. (2014). Paleoambientes e paleoclima durante o Aptiano na Bacia do Parnaíba (Formação Codó), Nordeste do Brasil. In I.S. Carvalho (Org.). Paleontologia: cenários da vida.(v.4, pp. 165173). Rio de Janeiro: Interciência.

Melo, M.T., \& Prade, G.O. (1968). Geologia da região Sudeste de São Raimundo das Mangabeiras - Maranhão. Belém: PETROBRÁS, DIREX/RENOR. (Relatório 297).

Plummer, F.B.; Price, L.I., \& Gomes, F.A. (1948). Estados do Marahão e Piauí. (pp. 87-134). Rio de Janeiro: Conselho Nacional de Petróleo (Relatório de 1946).

Ramos, M.I.F., Rosseti, D.F., \& Paz, J.D.S. (2006). Caracterização e significado Paleoambiental da Fauna de Ostracodes da Formação Codó (Neoaptiano), Leste da Bacia de Grajaú, MA, Brasil. Revisa Brasileira de Paleontologia, 9(3), 339-348.

Santos, M.E.C.M., \& Carvalho, M.S.S. (2009). Paleontologia das bacias do Parnaíba, São Luís e Grajaú. Reconstituições paleobiológicas. 2.ed. Rio de Janeiro. CPRM, Serviço Geológico do Brasil - DGM/DIPALE.

Vaz, P.T., Rezende, N.G.A., Wanderley Filho, J. R., \& Travassos, W.A. (2007). Bacia do Parnaíba. Boletim de Geociências da Petrobrás,15, 253-263.

Data de submissão: $27 /$ nov./2020

Data de aceite: 06/jul./2021 